Journal of

Business and Strategic

Management

(JBSM)

INFLUENCE OF PSYCHOSOCIAL FACTORS ON EMPLOYEES' PERFORMANCE IN ORGANIZATIONS

(A CASE OF HUDUMA CENTRE - NYERI COUNTY)

Caroline Waithira Kagwi

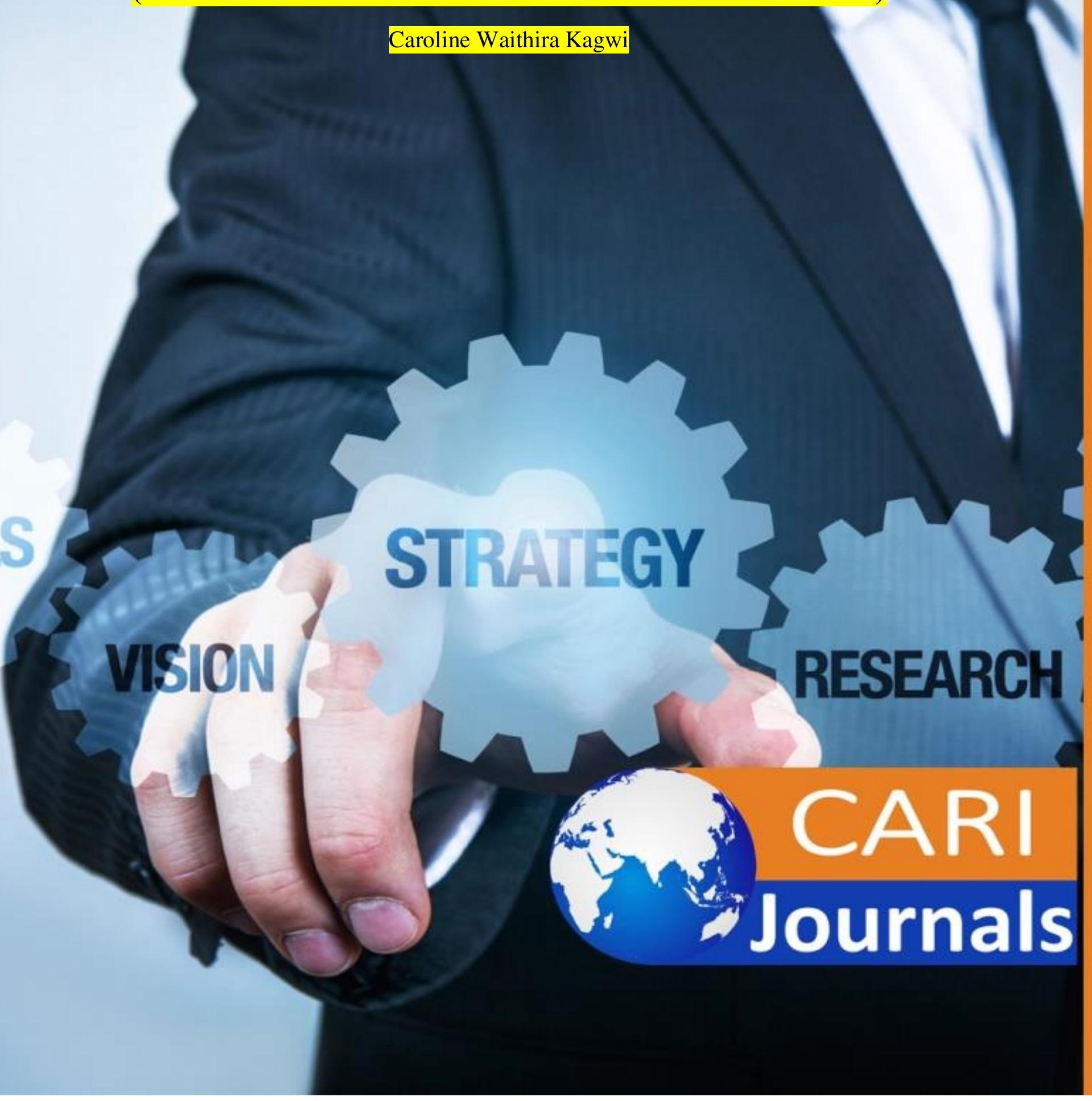




\title{
INFLUENCE OF PSYCHOSOCIAL FACTORS ON EMPLOYEES' PERFORMANCE IN ORGANIZATIONS (A CASE OF HUDUMA CENTRE - NYERI COUNTY)
}

\author{
${ }^{1 *}$ Caroline Waithira Kagwi \\ *Corresponding Author's Email: apecaro15@gmail.com
}

\begin{abstract}
Purpose: The purpose of this study was the investigation of psychosocial factors on the performance of employees; a case study of Huduma Centre Kenya-Nyeri county.

Methods: Descriptive research design was used and sample of 48 employees serving the 21 operational desks and 1 customer care desk was studied from the total population of 48 Huduma Centre-Nyeri County employees. During the study, data was collected from the respondents using questionnaires. Data analysis was done using Microsoft excel computer packages and information was presented through bar charts, tables and pie charts. The researcher evaluated various characteristics of a workplace environment.

Results: The findings indicated that psychosocial workplace aspects contribute to the success of individuals, groups, organizations, industries, and nations. It was established that psychosocial workplace aspects had a great contribution towards the organizations' performance in Huduma Centre, Nyeri County.

Unique contribution to theory, practice and policy: From the research carried out it is recommended that Supervisors interpersonal role is important to encourage positive relations and increase self-confidence of the employee and in return improve employee performance. Skilled and respected people are available to employees to help them to perform better in their current role and to assist them develop further into a future role. Immediate supervisors act as advocates for employees, gathering and distributing the resources needed by the employees for them to be able to do a good job and providing positive encouragement for a job well done.
\end{abstract}

Keywords: Psychosocial factors, Huduma Centre, employees, performance

\subsection{INTRODUCTION}

\subsection{Background of the Study}

Workplace environment is the sum of the interrelationships that exists within the employees and the environment in which they work (Kohun, 2002). According to Heath (2006), this environment involves the physical location as well as the immediate surroundings, behavioral procedures, policies, rules, culture, resources, working relationships, work location, all of which influence the ways employees perform their work. The quality of the workplace environment 
Journal of Business and Strategic Management

ISSN 2520-0402 (Online)

Vol.3, Issue 1 No.3, pp 31 - 44, 2018

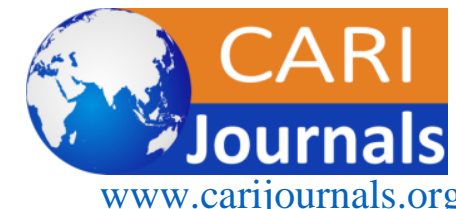

impacts on employees' performance and subsequently influences the organization competiveness.

An effective workplace environment management entails making work environment attractive, comfortable, satisfactory and motivating to employees so as to give employees a sense of pride and purpose in what they do (Humphries, 2005). Employees will and are always contented when they feel their immediate environment; both physical sensations and emotional states are in tandem with their obligations (Farh, 2012) and how well employees connect with their organization's immediate workplace environment, influences to a great extent their error rate levels, efficiency and innovativeness, collaboration with other employees, absenteeism and, ultimately their retention (Leblebici, 2012)

The type of workplace environment in which employees operate determines whether or not such organizations will prosper (Chandrasekhar, 2011). Physical workplace environment contextualizes the office layout and design while psychosocial factors include working condition, role congruity and social support from supervisors. Policies encompass employment conditions of employees derived from industrial instruments and agreements negotiated with employees and unions, along with our human resources policies. Employees spend fifty percent of their lives within indoor environments, which greatly influence their performance capabilities (Sundstrom, 1994). Better physical workplace environment will boosts employees' performance and ultimately improve their productivity (Challenger, 2000).

A healthy workplace environment makes good business sense and is characterized by respect that supports employee engagement and creates a high performance culture that encourages innovation and creativity (Kohun, 2002). Organizations deemed as a positive place to work will more likely have a competitive edge since they are in a better position to attract and retain highly skilled employees'. This is a significant consideration in the current tight labour market. A positive workplace environment is likely to result in less employee turnover, fewer cases of fraud, better safety practices, easier to attract and retain qualified employees and improved employees' wellbeing (Cunnen, 2006). In almost all high performing entities, one massage holds true above them all "People are an organization's most important asset (O’Neill, 2007).

\subsection{Huduma Kenya}

Huduma Kenya is a programme by the Government of Kenya that aims to transform Public Service Delivery by providing citizen's access to various Public Services and information from One Stop Shop citizen service Centres called Huduma Centres and through integrated technology platforms. Huduma Kenya provides Efficient Government Services at the Convenience of the citizen. (Dibondo, 2016)

Huduma Kenya is a 'one stop shop' approach in reforming service delivery in Kenya. Huduma Kenya involves amalgamating related services within one building, possibly on the same floor, effectively making it possible for service seekers to access it conveniently. This means that you will be able to get birth certificates, national identity cards, passports, registration of business names, and applications for marriage certificates, drivers' licences, police abstract and many other services in one place. 
Journal of Business and Strategic Management

ISSN 2520-0402 (Online)

Vol.3, Issue 1 No.3, pp 31 - 44, 2018

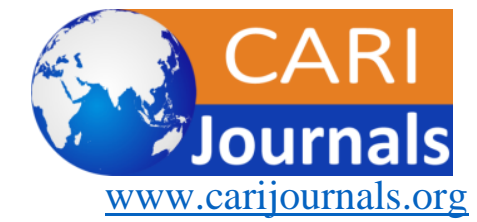

Among the changes to be introduced in the public service include introduction of one stop HCs to provide customer services to citizens from a single location, online e-Huduma web portal to provide integrated services offered by various government ministries, departments and agencies and a unified and integrated channel Huduma payment gateway to facilitate ease of payment for government services. (Global workforce study, 2012).

Others are introduction of m-Huduma platform to offer M-Government services to citizens from their mobile phones and a Huduma call Centre to provide customer service using a single dialing prefix (Saringi, 2015) Through the Huduma Kenya platform, the government aims at enabling citizens to access integrated public services via their phones, computers and personal digital assistants (PDA). The new portal is also expected to enhance service delivery and eradicate graft loopholes.

Tenders and vacancies in the public service will also be accessible on the platform. Users will also be able to directly post their comments and complaints regarding government services(Muraya, 2016) Other important information that will be readily available on the portal includes county government contacts, especially considering counties were recently formed with the promulgation of Kenya's new constitution. The HCs are found in regions in all the County headquarters like Nairobi, Kisii, Siaya, Kisumu, Mombasa, Nakuru, Nyeri, Thika, Muranga, Meru, Embu and many town Centres throughout the country.

\subsection{Statement of the Problem}

Creating a work environment which promotes wellbeing of employees and increase individual performance is viewed as a strategy for enhancing company efficiency and productivity. Avery, Volpone, McKay, King, and Wilson (2011) noted tardiness and absenteeism of full-time employees resulted in productivity losses for the organizations. Creating effective personal environments must account for both physical and psychosocial elements together with the constraints of cost and technology. It is felt in general that improving the workplace environment increases productivity. There are a number of interacting factors which effect productivity including light, temperature, noise, hygiene, furniture, as well as social issues.

Employee's normally have expectation and will demand a workplace environment that facilitates them to perform their work optimally. When this is sufficiently provided, it can boost organizational competitiveness (Heath, 2006). HCs make significant investments in designing, building and ultimately recruiting knowledgeable and experienced personnel. The immediate work environment in terms of actual physical layout and design of an office is extremely important when it comes to maximizing individual performance. Poorly designed workstations, unsuitable furniture, lack of ventilation, inappropriate lighting and excessive noise adversely affect employee performance (Becker, 2002).

In addition, incongruent psychosocial factors - the non-physical aspects of a workplace, such as working conditions, social support from supervisor and role incongruity also impacts negatively on employees' performance. The organization of work-life is also now a major consideration as they attempt to spur exceptionally high performance (Smith, 2010).

To institutionalize the right practices in work-life balance, the right policies and programs have to be put in place. Inadvertently, an imbalance between workplace environment factors and 
Journal of Business and Strategic Management

ISSN 2520-0402 (Online)

Vol.3, Issue 1 No.3, pp 31 - 44, 2018

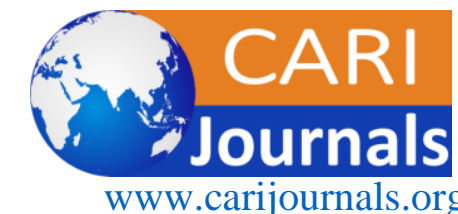

employee's needs, abilities and expectations, is being manifested in different HC, prompting diverse reactions.

The dimensions of physical, psychosocial work life balance and management system standards are still unclear in respect of how they affect performance in the HCs especially Nyeri County since the employees have report back to their back offices from which they are seconded. The studies that have looked at this phenomenon have limited themselves to customer satisfaction without paying attention to the workplace environment and especially from an employees' perspective (Global workforce study, 2012).

It has been noticed that many enterprises pay a lot of attention to employee productivity enhancement through acquisition of skills while research has shown that about $86 \%$ of productivity problems reside in the work environment of organizations (Taiwo, 2010). This indicated that perhaps other psychosocial factors are responsible and needed to be studied to establish how they influenced employee performance.

\subsection{The Specific Objective}

To examine the effect of psychosocial factors on the performance of employees

\subsection{LITERATURE REVIEW}

\subsection{Herzberg Hygiene / Motivation Theory}

According to this theory, people work first and foremost in their own self-enlightened interest, for they are truly happy and mentally healthy through work accomplishment. He looked at motivators and hygiene factors. Hygiene factors, often referred to as 'dissatisfiers', are elements in the work environment that include Supervision, Interpersonal relations and Working conditions. Motivators, often referred to as 'satisfiers', are aspects of the work environment that provide employees with job satisfaction and include recognition, work, responsibility and advancement. This theory contributed an insight into the study of employee by explaining how the 'dissatisfiers' and 'satisfiers' affected workplace environments on individual performance.

\subsection{Frederick Taylor's Scientific Management Theory}

Its main objective is improving economic efficiency, especially performance, monitor worker performance, and provide instructions and supervision to ensure that they're using the most efficient ways of working. Management can be defined as the process of designing and maintaining an environment in which individuals, working together in groups, efficiently accomplish selected aims (Chandrasekhar, 2011). In this study management was seen as a prelude to environments which in due process affected the manner in which employees perform.

\subsection{Psychosocial Factors Affecting Employees' Performance}

The psychosocial factor of work environment is generally considered to be one of the most important issues in contemporary and future societies. They refer to the interactions between the environment and working conditions, organizational conditions, functions and content of the work, effort, workers' individual characteristics and those of members of their families (Vischer, 2008). Therefore, the nature of the psychosocial factors is complex, covering issues relating to the workers, general environment and work. Noe (2008) define employee workplace welfare in 
Journal of Business and Strategic Management

ISSN 2520-0402 (Online)

Vol.3, Issue 1 No.3, pp 31 - 44, 2018

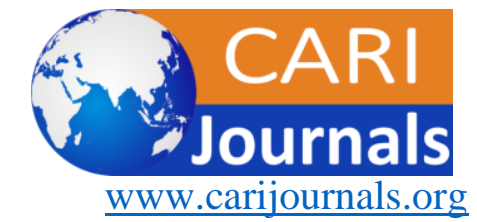

terms of six key areas: a manageable workload; some personal control over the job; support from colleagues and supervisors; positive relationships at work; a reasonably clear role; and a sense of control or involvement in changes at the workplace. Individual associations with the working environment are important as they impact upon the ability of the individual to take control of their work and the level of stress they experience within the workplace (Warr, 2002).

The behavioral factors that may affect the performance of employees at work place are the exclusive nature and function of job satisfaction change, or systematic development or weakening in job satisfaction over spell (Warr, 2002). There are lots of other aspects that may enhance or lower the employees' performance some of which include role congruity, supervisor support and leadership styles in Huduma Centre-Nyeri County rank among the factors that may individually and collectively effect on the performance of employees.

\subsubsection{Supervisor Support}

Supervisors are the first level of management who are given the major duties and responsibilities to form and lead work groups in organizations (Noe, 2008). Supervisor' interpersonal role is important since it encourages positive relations and increases self-confidence of the employees and in return improves performance (Arnold, 2007). Immediate supervisors act as advocate for employees, facilitates the allocation resources required by the employees for them to be able to do a good job and providing positive encouragement for a job well done. In order to gain the employees performance, both parties needs to play their part which is to commit with the relationship hence sustain performance (Bauer \& Green, 2000).

According to Gilbert (2005) supervisor support on performance is determined by different factors, some of them related to the individual performer (such as individual ability and capacity, skills and knowledge, and motivation), others coming from the organizational context (such as standards and expectations, feedback and communication, task support and incentives). Those seven factors interact regularly in a performance system, where inputs (what the performer has), processes (what the performer has to do), and outputs (what has to be accomplished) have to be aligned in order not only to achieve, but to sustain performance. They should thus supervise the performance of the workers and then provide instructions and give feedback to them to ensure that they maximize their efficiency. This study therefore sought to study how social and supervisor supported in the workplace environments can influence performance of the employees.

\subsubsection{Role Congruity}

The role that the employee is required to perform is consistent with their expectations on joining the organization and any subsequent job orientations. An organization's role expectations are typically reflected in formal documents, such as job design, job descriptions and analysis and role specifications. These expectations are in line with responsibilities allocated by the employee's immediate supervisor.

A job description is a written statement that explains the purpose, scope, duties and responsibilities of a specified job. It is prepared based on job analysis for internal use within the Huduma Centre Kenya and external use to gain the attention of people outside the organization. Job descriptions can be used as a roadmap for recruitment, selection and orientation. They are 
Journal of Business and Strategic Management

ISSN 2520-0402 (Online)

Vol.3, Issue 1 No.3, pp 31 - 44, 2018

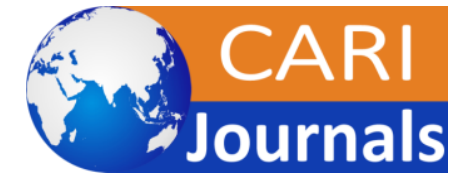

WWW.carijournals.org

also the building blocks used in performance assessment, succession planning, coaching, training and compensation. A job description helps to ensure effective performance and provides a clear guide to all that are involved about the position, its requirements and expected outcomes (Gomes, 2010). Job descriptions are subject to constant change and shift due to the nature of the environment in organizations and businesses. Organizational changes such as restructuring, growth, cutbacks and reassignments have a direct impact on job descriptions (Arnold, 2007). It is important to know how changes affect relationships between positions and help identify possible overlaps or gaps between jobs.

Job design is the process of organizing tasks that are required to perform a job (Gomes, 2010). In a stable workplace environment, work simplification can be an effective way to organize labor and improve performance. In a service environment where employees perform simplified and highly specified jobs, job enlargement and job rotation can be good ways to create variation in the duties. Job enlargement expands duties and responsibilities and job rotation moves workers in different duties without disrupting the flow of work. Job enrichment attempts to improve employee performance by putting specified parts of the work back together so that one person produces a satisfactory service.

Job analysis is the process of collecting information about the content of a specific job. The purpose of job analysis is to identify the differences and similarities between different jobs and attain knowledge and requirements on jobs in the organization (Gomes, 2010). Job analysis is a prerequisite for preparing a job description and job evaluation. It should include information about the nature and purpose of the job; tasks included, expected outcomes and position in the organizational hierarchy. The job holder's characteristics should also be seen on the job analysis. Job analysis consists of collecting data and applying it by preparing job descriptions, job specification and job standards (Arnold, 2007).

Any job requires creativity, enthusiastic environment and challenging goals to accomplish. If the job content is challenging and innovative then the employees are willing to give positive output. If the job tasks are creative and attainment of goal is necessary, then the employees give tend to perform better. For this job enrichment and job rotation is important. Employees get bored of doing the same routine task all the time. Innovation and creativeness enhance the employees' performance. This study therefore sought to investigate the role of role congruity in the workplace environment on the performance of employees.

\subsubsection{Leadership Style}

Leadership style is crucial since it determines the quality of employee's performance. It is an interaction between leaders and employees where the leaders control and direct them in attempts to influence their behavior to spur performance (Northouse, 2010). According to Kavanaugh and Ninemeier (2001), there are three factors that determine the type of leadership style: leaders' characteristics, subordinates' characteristics and the organization environment. More specifically, the personal background of leaders such as personality, knowledge, values, and experiences shapes their feelings about appropriate leadership that determine their specific leadership style. Employees also have different personalities, backgrounds, expectations and experiences, for example, employees who are more knowledgeable and experienced may work well under a democratic leadership style, while employees with different experiences and 
expectations require an autocratic leadership style. Some factors in the organization environment such as organizational climate, organization values, composition of work group and type of work can also influence leadership style (Chen and Silverthorne, 2005). However, leaders can adapt their leadership style to the perceived preferences of their subordinates (Wood, 1994).

\subsection{Conceptual Framework}

\section{Psychosocial Environment}

- Supervisor support

- Role Congruity

- Quality Leadership

Independent variables

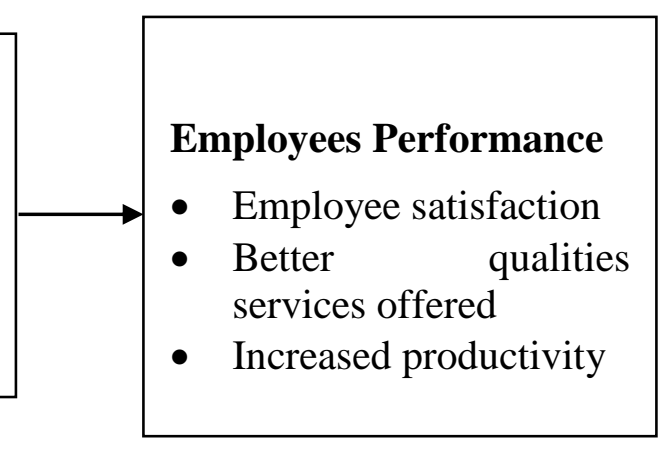

Dependent variable

\subsection{RESEARCH METHODOLOGY}

The study adopted a descriptive survey design in investigating the effects of physical environment on employee performance in Huduma Centre-Nyeri County. The research targeted the employees from Huduma Centre-Nyeri County. A sample of 48 employees serving the 21 operational desks and 1 customer care desk was studied from the total population of 48 Huduma Centre-Nyeri County employees. The researcher conducted a census. The researcher used questionnaires to collect data from the Huduma Centre-Nyeri County employees. The researcher used a drop and pick later method in the administration of the questionnaire. To establish construct validity of the instrument the researcher sought expert opinion from the university supervisors. The researcher measured the reliability of the questionnaire to determine its consistency in testing what they are intended to measure (Nachmias and Nachimias, 1996). The test re-test technique was used to estimate the reliability of the instruments. This involved administering the same test twice to the same group of respondents who had been identified for this purpose. This study used descriptive statistical techniques, which included percentages, ranking, scales and averages to analyze the data. Data collected from the study was organized, classified, edited, coded and analyzed by use of percentages and frequencies and then presented in tables, graphs and pie charts.

\subsection{DATA ANALYSIS AND PRESENTATION}

\section{1: Response Rate}

The target population of this study was all employees of Huduma Centre -Nyeri County. A total of 48 respondents were considered for the study though the research response rate of participants was 45 respondents which the researcher found significant for the study. 
Journal of Business and Strategic Management

ISSN 2520-0402 (Online)

Vol.3, Issue 1 No.3, pp 31 - 44, 2018

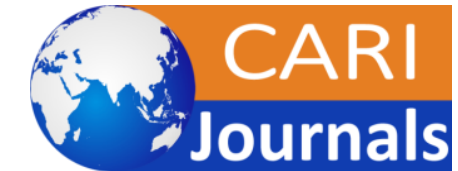

WWW.carijournals.org

Table 1 Response Rate

\begin{tabular}{lcc}
\hline Response rate & Frequency & Percentage (\%) \\
\hline Responded. & 45 & $93.7 \%$ \\
Did Not respond. & 3 & $6.3 \%$ \\
Totals & $\mathbf{4 8}$ & $\mathbf{1 0 0 \%}$ \\
\hline
\end{tabular}

4.2 Age

The study covered respondents from 20-29 years, 30-39 years, 40-49 years and above 50 years. The data analysis results are presented in pie chart below.

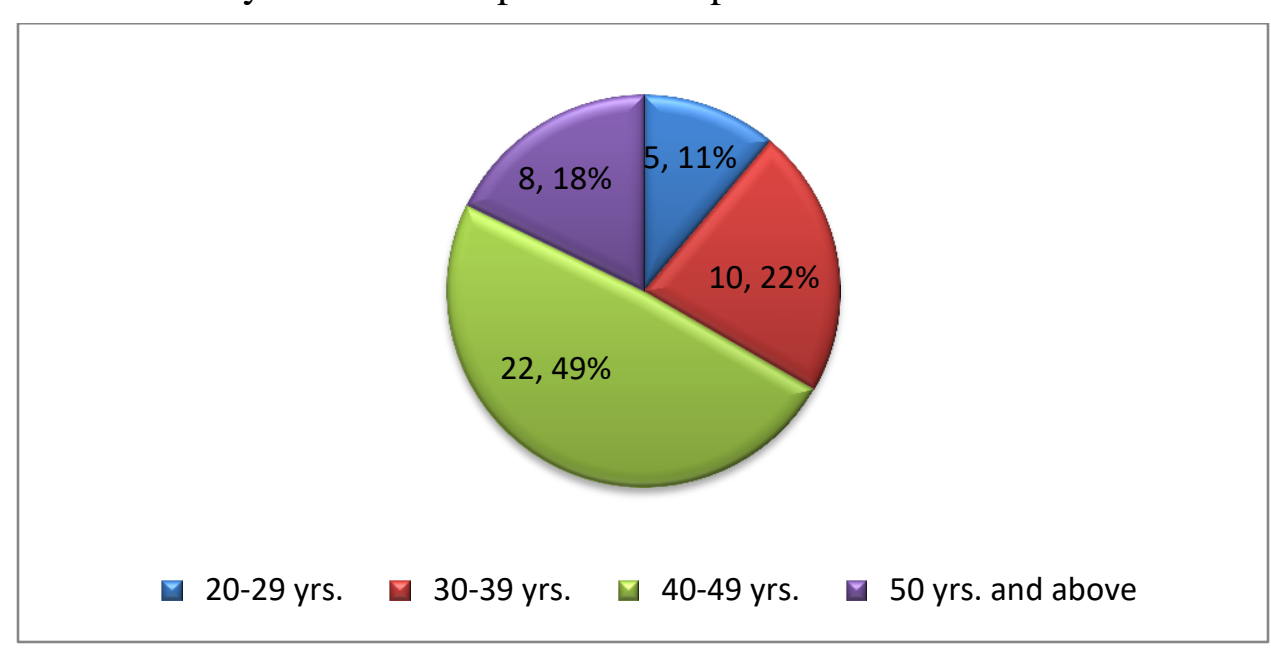

\section{Figure 1: Source (Researcher 2017)}

From the above chart, the study found that the biggest populations of all the respondents were aged between 40-49 years and represented $49 \%$ of the population, followed by those between ages 30-39 years and represented $22 \%$ of the population while 50 years and above wer 8 represented $18 \%$ of the total population, above between $20-29$ years were 5 represented $11 \%$ of the entire population.

\subsection{Gender}

This study sought to establish the gender of the respondents. The information gathered was necessary to establish the nature and characteristics of the gender involved in the study. The data analysis results are presented in the figure below. 


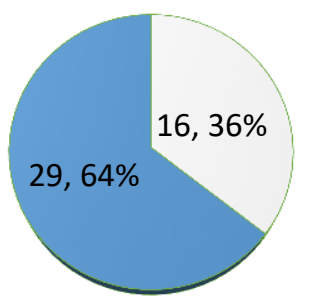

male

female

Figure 2: Gender, Source (Researcher 2017)

From the above table, it is evident that a population of 45 respondents was considered, out of which $56.8 \%$ were female and $43.2 \%$ of the populations were males. Therefore from the above findings female were found to represent the highest population of the study.

\subsection{Marital Status}

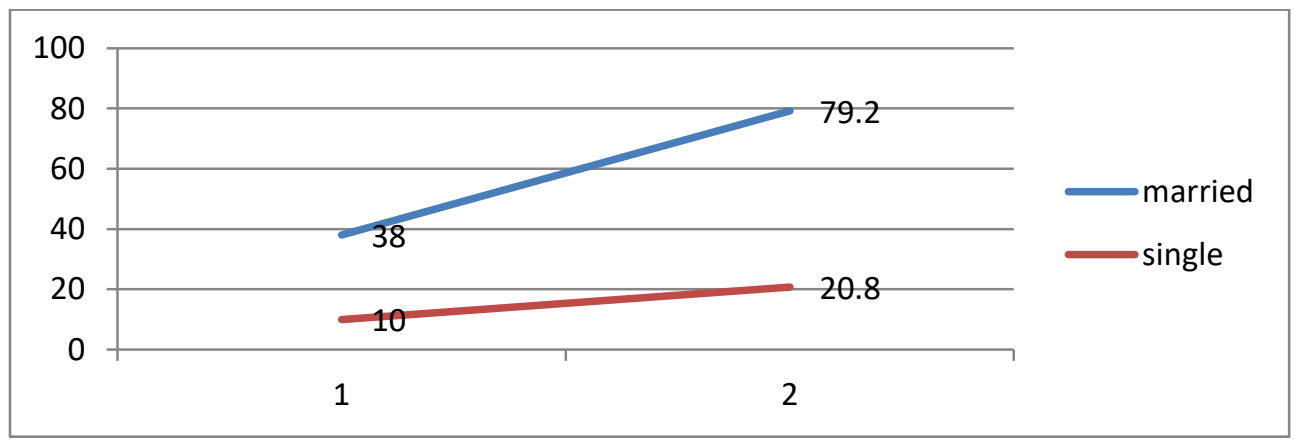

Figure 3: Marital Status, Source (Researcher 2017)

From the above figure, of 45 respondents were considered, out of which 10 (20.8\%) were Single, 38(79.2\%) were Married none among the respondents was Divorced, Widowed or Widow. Therefore from the above findings married employees were found to represent the highest population of the study.

\subsection{Tenure of your job}

This sought to establish the tenure of employment of the respondents. The information gathered was necessary to establish the nature and characteristics of the employees involved in the study. The data analysis results are presented in the table below. 5(10\%) were on Contract basis, 43(90\%) were on Permanent basis and none was working on Part-time 


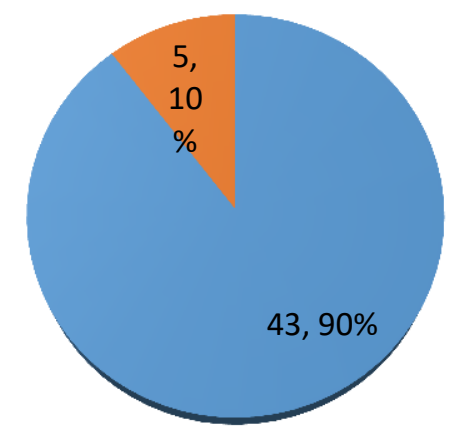

Permanent

Contract

Figure 4: Tenure of job, Source (Researcher 2017)

\subsection{Years in the organization}

Figure 5 illustrates that majority 18(40\%) of the respondents had a working experience for between 4-6 years. In addition, another 13 (29\%) had worked for 7-9 years, those who had worked for 1- 3 years were 6(13\%), those who had worked for over 10 years were 5(11\%) and the least was $3(7 \%)$ having worked less than 1 year. This indicated that they had the knowledge and experience of their respective departments at Huduma Centre -Nyeri County and therefore offered credible information towards the study.

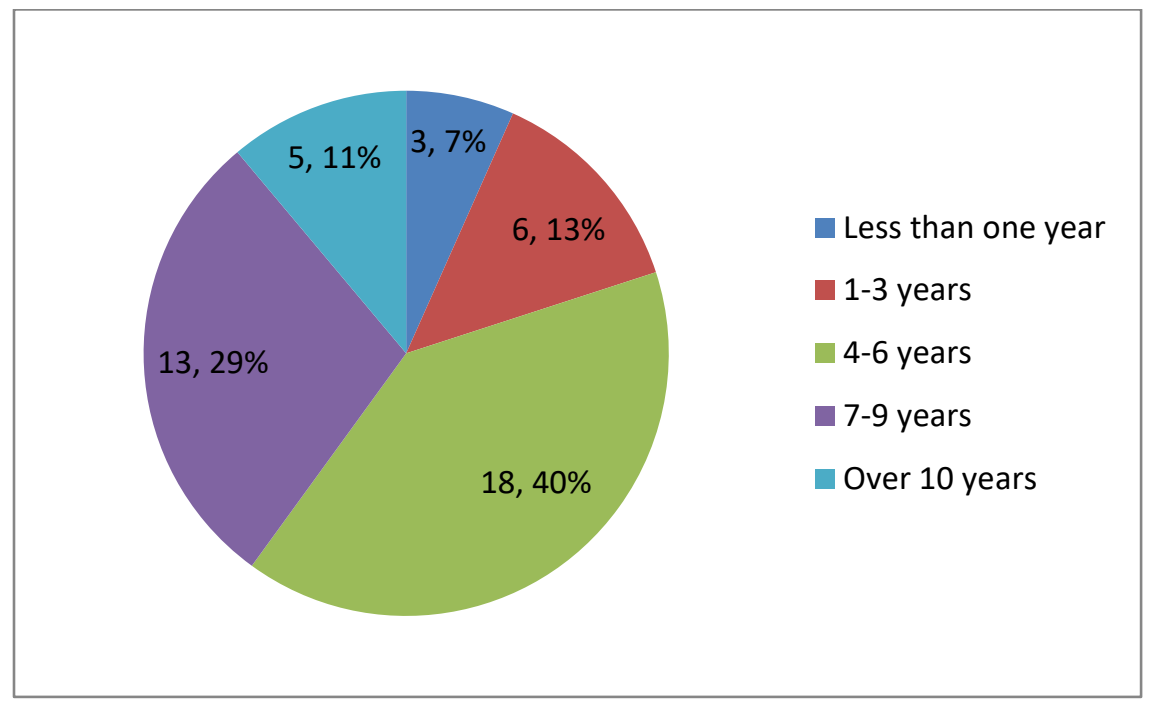

Figure 5: Years in the organization, Source (Researcher 2017)

\subsection{Psychosocial Workplace Aspects}

The researcher investigated whether Psychosocial Workplace Aspects had any effect on employees' performance. From the research findings, it was found that, on meeting frequently with their supervisors $16(33 \%)$ respondents strongly agreed, 20(42\%) had an agreed opinion, $5(11 \%)$ respondent were Neutral, 4(8\%) respondents Disagreed and $3(6 \%)$ strongly disagreed. On the respect to workers' opinions $23(48 \%)$ respondents strongly agreed, $13(27 \%)$ had an 
agreed opinion, 8(17\%) respondent were Neutral, 2(4\%) respondents Disagreed and 2 (4\%) strongly disagreed. Investigation on clear roles and responsibilities 20(42\%) respondents strongly agreed, 18(38\%) had an agreed opinion, 5(10\%) respondent were Neutral, 3(6\%) respondents Disagreed and 2(4\%) strongly disagreed. On the findings on managers' communication $17(35 \%)$ respondents strongly agreed, 20(42\%) had an agreed opinion, 6(13\%) respondent were Neutral, 2(4\%) respondents Disagreed and 3(6\%) strongly disagreed. Response on managers' assistance was as indicated, 20(42\%) respondents strongly agreed, $24(50 \%)$ had an agreed opinion, 2(4\%) respondent were Neutral, 1(2\%) respondents Disagreed and 1 (2\%) strongly disagreed. Investigation on whether a job has a wide range performance findings were that $22(49 \%)$ respondents strongly agreed, 17(38\%) had an agreed opinion, 3(7\%) respondent were Neutral, 2(4\%) respondents Disagreed and 1 (2\%) strongly disagreed.

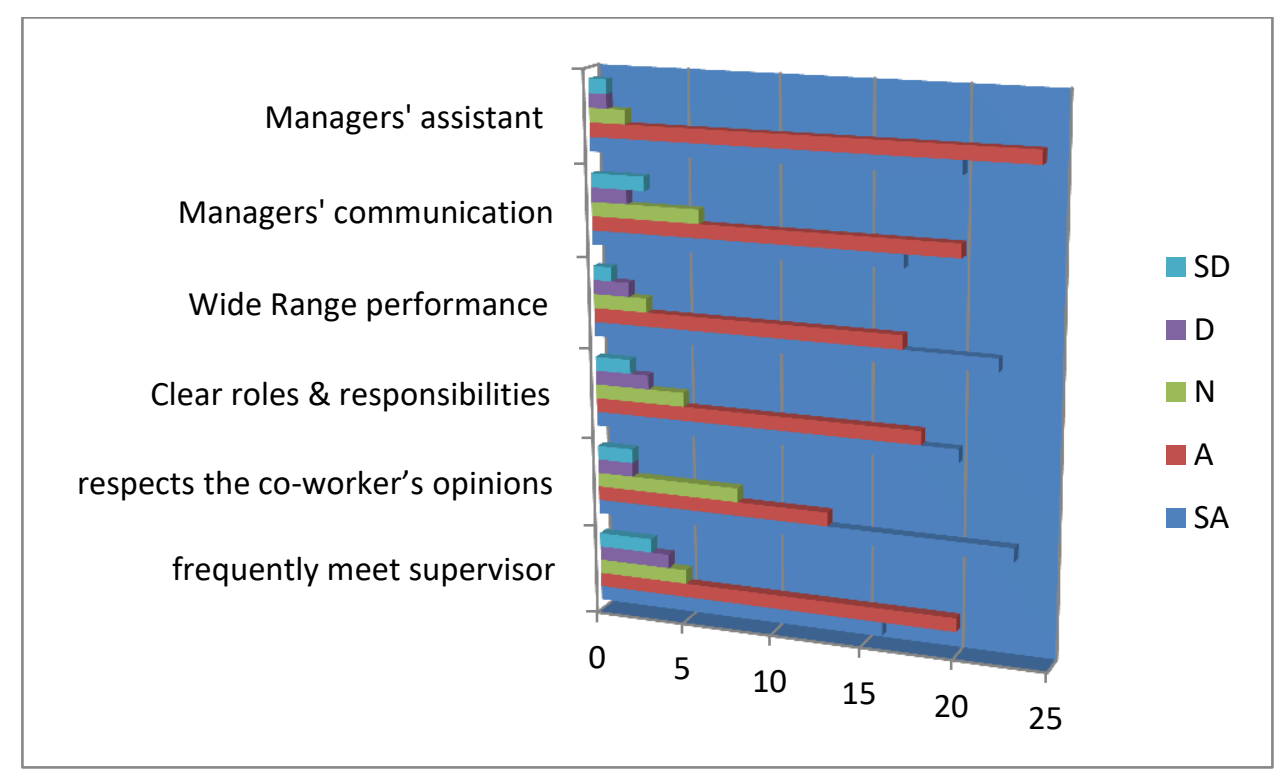

Figure 6: Psychosocial Workplace Aspects

Source (Researcher 2017)

\subsection{SUMMARY, CONCLUSIONS AND RECOMMENDATIONS}

\subsection{Summary of the Findings}

This study specifically sought to investigate the effect of psychosocial workplace factors on performance of employees a case of Huduma Centre in Nyeri County. The researcher evaluated various characteristics of a workplace environment. The findings further indicated that psychosocial workplace factors contribute to the success of individuals, groups, organizations, industries, and nations.

It was established that psychosocial workplace aspects had a contribution towards the organizations' performance in Huduma Centre, Nyeri County. 
Journal of Business and Strategic Management

ISSN 2520-0402 (Online)

Vol.3, Issue 1 No.3, pp 31 - 44, 2018

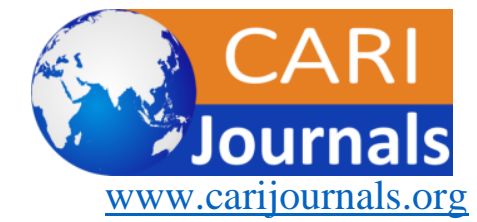

For Employees' performance to be effective the findings highlighted Managerial standards should be considered as they can be a factor in motivating or de-motivating employees. Managing the strengths of the internal operations and recognizing potential opportunities and threats outside of the operations are keys to business success. The strength of your employees is another crucial internal business factor. Motivated, hard-working and talented workers generally produce better results than unmotivated, less-talented employees. Your business processes and relationships within and between departments and employees also significantly impact business effectiveness and efficiency. In a high-performing workplace, employees not only have talent, but they work well together and collaborate on ideas and resolutions.

\subsection{Conclusion}

Employees that feel as though the company has made a commitment to employee success tend to perform better, according to Personnel Systems Associates. Commitment means offering a competitive rate of pay and benefits package, offering assistance in paying for employee's higher education costs, developing a regular training schedule that keeps employees updated on company changes and gives pertinent information for employees to do their jobs and upgrading equipment to make sure that employees have the most efficient technology available to do their work. Commitment shown by the company is returned in the form of commitment from employees.

An effective employee evaluation is an interactive process where the manager gives his input on the employee's performance, and the employee gets the chance to point out what she has learned throughout the year. Managers create a plan along with the employee for the coming year on how the employee can develop and improve their performance. Comprehensive employee evaluations are important to the ongoing performance of employees.

To get the best performance from employees, there needs to be some sort of motivation beyond the weekly paycheck. Motivation can come in the form of financial incentives, the opportunity to get involved in company projects, a career path that leads to management and direct involvement from management into the daily tasks. Effective motivation can create a productive work force, but a lack of motivating factors can leave employees searching for reasons to give their maximum effort.

Those factors over which an individual has no control, such as the job may have been completed under severe time constraints, with a lack of adequate resources, or by using obsolete equipment; there may have been conflicting priorities or information overload, such that the individual was confused and under stress; other staff and departments may have been less than cooperative; the restrictive policies of the organisation may have prevented the individual from using her initiative and imagination to the extent that she wished; the quality of the supervision exercised may have been defective - some people need encouragement and support, whereas others like to be left to get on with the job. Cannot be used as excuses for poor performance, but they do have a modifying effect.

\subsection{Recommendations}

From the research carried out it is recommended that Supervisors interpersonal role is important to encourage positive relations and increase self-confidence of the employee and in return 
Journal of Business and Strategic Management

ISSN 2520-0402 (Online)

Vol.3, Issue 1 No.3, pp 31 - 44, 2018

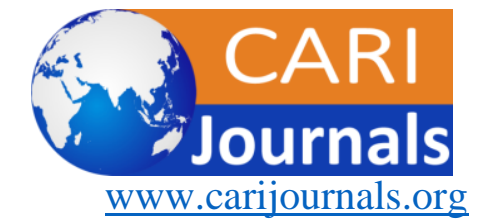

improve employee performance. Skilled and respected people are available to employees to help them to perform better in their current role and to assist them develop further into a future role. Immediate supervisors act as advocates for employees, gathering and distributing the resources needed by the employees for them to be able to do a good job and providing positive encouragement for a job well done.

\section{REFERENCES}

Anderson, S. E., Coffey, B. E., \& Byerly, R. T. (2002). Formal organizational initiatives and Approaches.Nairobi: Africa Centre for Technology Studies (ACTS).

Armstrong, M. (2006). Performance Management: Key Strategies and Practical guidelines,Approaches. Nairobi: Africa Centre for Technology Studies (ACTS).

Arnold \& Freidman (2007) Supervision and Employee Perception. Journal on Comparative

Babbie, E. (2002). Survey research methods. 2nd ed. Belmont, CA: Wadsworth Publishing.

Badu, K. (1994). Monetary Economics in the Developing Countries, Money and economics.

Becker, F. (2002). Improving organizational performance by exploiting workplace flexibility.

Bhatti, N. (2007) Bank Performance Measure, Efficiency and Effectiveness Journal Bodmin, Cornwall: MPG Books ltd.

Briner, R.B. (2002), Relationship between work environments, psychological EnvironmentsCase Study of Faulu Kenya.

Challenger, J.A. (2000). 24 Trends reshaping the workplace. The Futurist, 35-41.

Chandrasekhar, K. (2011). Workplace environment and its impact on organizational Performance, International Journal of Business Systems, Vol. 7, pp. 17-18.

Chen, J. \& Silverthorne, C. (2005). Leadership effectiveness, leadership style and employee readiness. Leadership \& Organization Development Journal, 26(4): 280-288.

Farh, C. C.; Seo, Tesluk (2012). "Emotional Intelligence, Teamwork Effectiveness, \& job Financial and Banking Studies.

Gilbert, T. (2005. Human Competence. New York, NY; John Wiley

Global Workforce Study, (2012). Engagement at Risk: Driving Strong Performance in a Volatile Global Environment. Towerswatson.com/sustainable-employee-engagement.

Govindarajulu N, Bonnie, F. Daily. (2004). Motivating Employees for Environmental and wellbeing. Department of organizational psychology. 50, 299-303.

Gutnick, L. (2007). A workplace design that reduces employee stress and increases employee Indoor environment practicable? Building Research and Information, 33(4), 317-325.

Haynes, B.P. (2008). The Impact of office comfort on productivity. Journal of Facilities

Heath, B. (2006). Effect of perceived work environment on employee's job behavior and Empirical investigation", Strategic Management Journal, Vol. 7 No.2, pp.217-31. 
Journal of Business and Strategic Management

ISSN 2520-0402 (Online)

Vol.3, Issue 1 No.3, pp 31 - 44, 2018

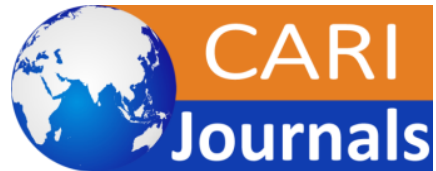

WWW.carijournals.org

Humphries, M. (2005). Quantifying occupant comfort: Are combined indices of the Improvement. Industrial Management and Data Systems.International Journal of Business \& Management, 6(4), 168-177

Informal workplace practices: Links to work-family conflict and job-related outcomes. Journal of Management, 28(6), 787-810.

Kohun, (2002). Workplace Environment and its impact on organizational performance in \& organizational effectiveness, Journal of Applied Psychology Banarashindu,

Leblebici,D.(2012). Impact of Workplace Quality on Employee's Productivity:

Nachmias and Nachmias, (1996).Study guide for research methods in the social science.

Noe, R.A. (2008). Employee training and development, New York: McGraw Hill

Northouse, P.G. (2010). Leadership: Theory and Practice. (3rd Ed). California: Sage

Organizational effectiveness, Journal of Applied Psychology Banarashindu,University, Varanasi. Oxford: Butterworth- Heinemann Ltd.

Physical Environment in Office. Cambridge University Press. New York.

Public sector organizations, International Journal of Enterprise Computing and Business System International Systems, Vol. 1 Issue 1 January 2011.

Smith, K. T. (2010). Work-life balance perspectives of marketing professionals in generation Performance: The Moderating Role of Job Context”. Journal of Applied Psychology

Sundstrom, E., Town, J.P., Rice, R.W., Osborn, D.P. and Brill, M. (2009). Office noise,

Taiwo, A.S. (March 2010). The Influence of Environment on Workers' Productivity: Team Performance Management, 15(1/2), 35-48.

Vischer, J.C. (2008). Towards an environmental psychology of workplace: How people are Wales. John Wiley \& Sons.University, Varanasi.

Warr, P. (2002). Psychology at work, London: Penguin Books.

Wood, R.C. (1994). Organizational Behavior for Hospitality Management. (1st Ed.).

World at work, (2007). Environmental Performance: Form Strategy to Implementation \&Services Marketing Quarterly, 31(4), 434-447. 